\title{
Fine-Root Decomposition and Nutrient Return in Moso Bamboo (Phyllostachys pubescens J.Houz.) Plantations in Southeast China
}

\author{
Yaowen Xu',2, Runxia Huang ${ }^{1,2}$, Benzhi Zhou ${ }^{1,2 *}$ and Xiaogai Ge ${ }^{1,2}$ \\ ${ }^{1}$ Research Institute of Subtropical Forestry, Chinese Academy of Forestry, Hangzhou, China, ${ }^{2}$ Qianjiangyuan Forest \\ Ecosystem Research Station, National Forestry and Grassland Administration of China, Hangzhou, China
}

OPEN ACCESS

Edited by:

Durgesh Kumar Tripathi, Amity University, India

Reviewed by:

Corina Carranca, Instituto Nacional de Investigação Agrária e Veterinária, I. P. (INIAV).

Portugal

Abhishek Kumar Dwivedy, Banaras Hindu University, India

${ }^{*}$ Correspondence: Benzhi Zhou benzhi_zhou@126.com

Specialty section: This article was submitted to Plant Nutrition, a section of the journal Frontiers in Plant Science

Received: 02 July 2021 Accepted: 17 January 2022

Published: 07 February 2022

Citation:

$X u$ Y, Huang R, Zhou B and Ge X (2022) Fine-Root Decomposition and Nutrient Return in Moso Bamboo (Phyllostachys pubescens J.Houz.) Plantations in Southeast China.

Front. Plant Sci. 13:735359.

doi: 10.3389/fpls.2022.735359
Plant fine-root decomposition is an important pathway for the reentry of nutrients into the soil. Studies have mainly focused on the loss of fine-root mass and the release characteristics of major elements, including, $\mathrm{C}, \mathrm{N}$, and $\mathrm{P}$, but there are few reports on trace elements. In this study, in situ decomposition experiments were conducted to study the dynamic characteristics of mass loss and residual rates of 10 mineral elements in two diameter classes ( $<2 \mathrm{~mm}$ and $2-5 \mathrm{~mm}$ ) of moso bamboo in the process of fineroot decomposition. The results of the year-long experiment reported herein showed that: (1) fine roots with diameters of less than $2 \mathrm{~mm}$ decomposed faster than those with diameters of 2-5 mm; (2) C, N, P, K, Ca, and Mg were released, whereas Fe, Mn, Zn, and $\mathrm{Cu}$ were enriched or changed little; (3) decomposition time and root diameter had significant effects on the remaining percentages of $\mathrm{C}, \mathrm{N}, \mathrm{K}, \mathrm{Ca}, \mathrm{Mg}, \mathrm{Mn}, \mathrm{Zn}$, and $\mathrm{Cu}$, and there were interactions among the elements $(P<0.05)$. The remaining percentages of $P$ and Fe were only affected by decomposition time. This is the first comprehensive report on the variation in 10 elements during the fine-root decomposition of moso bamboo. The study expands our understanding of the release of mineral nutrients during fineroot decomposition, laying a solid theoretical foundation for further research on fine-root decomposition and plant-soil nutrient cycling.

Keywords: root diameter, litter, mass loss, decomposition period, release, enrichment

\section{INTRODUCTION}

Bamboo is one of the most important non-wood forest products in the world and is an excellent alternative for wood production; hence, it is termed, "the second largest forest in the world" (Yang et al., 2021). In China, moso bamboo (Phyllostachys pubescens J.Houz.) forests are among the most important plantations in subtropical areas, with 4.56 million hectares, which accounts for $74 \%$ of all bamboo forests in the country (Yang et al., 2021). Compared with most other forest types, moso bamboo shows higher biomass productivity and a shorter rotation period ( $4-5$ years) (Buckingham et al., 2011). Indeed, in addition to producing numerous economically valuable products, due to their great primary productivity, moso bamboo forests produce a large amount of litter as well.

Abbreviations: C, carbon; N, nitrogen; P, phosphorus; K, potassium; Ca, calcium; Mg, magnesium; Fe, iron; $\mathrm{Zn}$, zinc; $\mathrm{Cu}$, copper; Mn, manganese. 
An experiment on broadleaf, coniferous, and bamboo litters showed that litter decomposition not only plays a key role in the material cycle of forest ecosystems but also plays an important role in the energy flow in these ecosystems (Dunmei et al., 2018). Besides aboveground litter, fine roots also account for a large proportion of primary productivity distribution in forest ecosystems and play an important role in nutrient cycling (Fujimaki et al., 2008). Furthermore, although fine roots only account for a small part of the total forest biomass (3-30\%), they have a large surface area and high-rate physiological activity and are the main organs for tree water and nutrient absorption (Yuan and Chen, 2010). Concomitantly, fine roots grow and turnover rapidly, thus playing an important and active role in the nutrient cycle of trees. As fine roots release nutrients to the soil throughout the year, they therefore contribute as much as $25-80 \%$ to the soil organic carbon pool every year and provide $29-225 \mathrm{~kg} \mathrm{~N} / \mathrm{hm}^{-2}$ (Usman et al., 2000).

In most forest ecosystems, $40-90 \%$ of newly generated roots will die within 1 year but their total growth can account for 50$75 \%$ of the forest primary productivity (Hendrick and Pregitzer, 1992). The amount of organic matter transferred to the soil through fine roots is one to several times that transferred by aboveground litter. Therefore, if the production, death, and decomposition of fine roots are ignored, the turnover of soil organic matter and nutrient elements will be underestimated by 20-80\% (Vogt et al., 1986). Thus, in order to further understand the nutrient dynamics of forest ecosystems, we should not ignore the study of fine-root decomposition while studying the decomposition of aboveground litter.

The initial contents of different mineral elements in fine roots are different, as are the roles they play in plants. Therefore, the changes in concentration of these elements in the process of fine-root decomposition are also different; furthermore, the main patterns of change in mineral element contents are release-enrichment-release, enrichment-release, and direct release (Blair, 1988). Release occurs mostly at the early stage of fine-root decomposition, and the duration of enrichment varies with the type of element (He et al., 2019). In many cases, enrichment and release occur alternately, which inevitably presents an irregular fluctuation of the remaining ratio of different elements in the process of fine-root decomposition. To date, studies have mainly focused on the mass loss of fine roots and the release characteristics of carbon (C), nitrogen $(\mathrm{N})$, and phosphorus $(\mathrm{P})$, while studies on trace elements are scarce (Xu et al., 2013; Wang et al., 2014). Although the trace element content is small, these elements are of great significance to plant physiology and ecology; therefore, it is necessary to bolster the study of trace elements in order to comprehensively understand the rules of fine-root decomposition and plant nutrient release to the soil.

The Miaoshanwu Experiment Forests of Qianjiangyuan Forest Ecosystem Research Station are located in Zhejiang Province, China. The typical vegetation in this area is subtropical, natural, broad-leaved secondary forest and artificial forests including, moso bamboo forests, Chinese fir forests (Cunninghamia lanceolata), and mass on pine forests (Pinus massoniana). The moso bamboo forest was planted in this region in the 1960s and the 1970s, and is an artificial forest typical of south China. In this study, the fine roots of moso bamboo were collected from the Miaoshanwu Nature Reserve. The decomposition rate of fine roots of two different diameters and the dynamic changes in different mineral elements during the process of decomposition were analyzed through a 12-month field experiment. The objectives of this study were as follows: (a) to analyze the decomposition rate of fine roots of moso bamboo of different diameters, and (b) to analyze the remaining percentage and release patterns of different nutrient elements during fine-root decomposition of moso bamboo.

\section{MATERIALS AND METHODS}

\section{Study Area}

The study was conducted in the Miaoshanwu Experiment Forests of Qianjiangyuan Forest Ecosystem Research Station, which are located in Fuyang, Zhejiang Province, China $\left(30^{\circ} 03-30^{\circ} 06 \mathrm{~N}\right.$; $119^{\circ} 56-120^{\circ} 02 \mathrm{E}$ ) (Figure 1). The study area belongs to the southeast offshoot of the Tianmushan Mountain Range, a major mountain range in southeast China. The elevation of the area ranges from 70 to $530 \mathrm{~m}$. The region is characterized by an intermediate, subtropical, monsoon, humid climate with a mean annual temperature of $16.1^{\circ} \mathrm{C}$. The annual precipitation ranges from 1001.7 to $1964.4 \mathrm{~mm}$, with a mean of $1441.9 \mathrm{~mm}$, which mainly occurs between March and August. The average annual sunshine duration is $1995 \mathrm{~h}$, and the frost-free period is 232 days per year. The soil is a yellowish-brown lateritic soil type with a thickness varying between 30 and $100 \mathrm{~cm}$. The slope varies between 15 and $30^{\circ}$. The physicochemical properties of the soil are listed in Table 1. Moso bamboo forests in this area maintain a structure of 1-5 years of age. Moso bamboo stands have diameters of 6-13 cm at breast height and are 7-14 $\mathrm{m}$ high, and stand density varies between 1600 and 2200 individuals/ha.

\section{Collection and Treatment of Fine-Root Samples}

A representative moso bamboo forest was selected in the Miaoshanwu Experiment Forests, and a 3-m-wide transect along the slope was set up. Approximately $3 \mathrm{~kg}$ of plant roots in the $0-20 \mathrm{~cm}$ soil layer was collected by the excavation method. The excavated roots were cut and cleaned, and the dark and inelastic dead roots were removed. Then the samples were packed in a selfsealing bag and transported to the laboratory at low temperature for preservation.

In this study, fine roots were divided into two groups: one group was less than $2 \mathrm{~mm}$ in diameter (RDC2), and the other group was 2-5 mm in diameter (RDC5) (Fujimaki et al., 2008). The buried litter bag method was adopted to measure fine root mass and element residual ratio (Fujimaki et al., 2008). The collected fine roots were divided into these two groups, washed, naturally air-dried, and then placed in nylon litter bags [1.5-mm mesh, $30 \mathrm{~cm} \times 30 \mathrm{~cm}$, weighing $10 \mathrm{~g}$ (9.23 g after drying)]. Eighty such litter bags were prepared (40 for RDC2 and 40 for RDC5). Two homogeneous quadrats $(10 \mathrm{~m} \times 10 \mathrm{~m})$ were randomly selected from the selected sample plot and the soil 


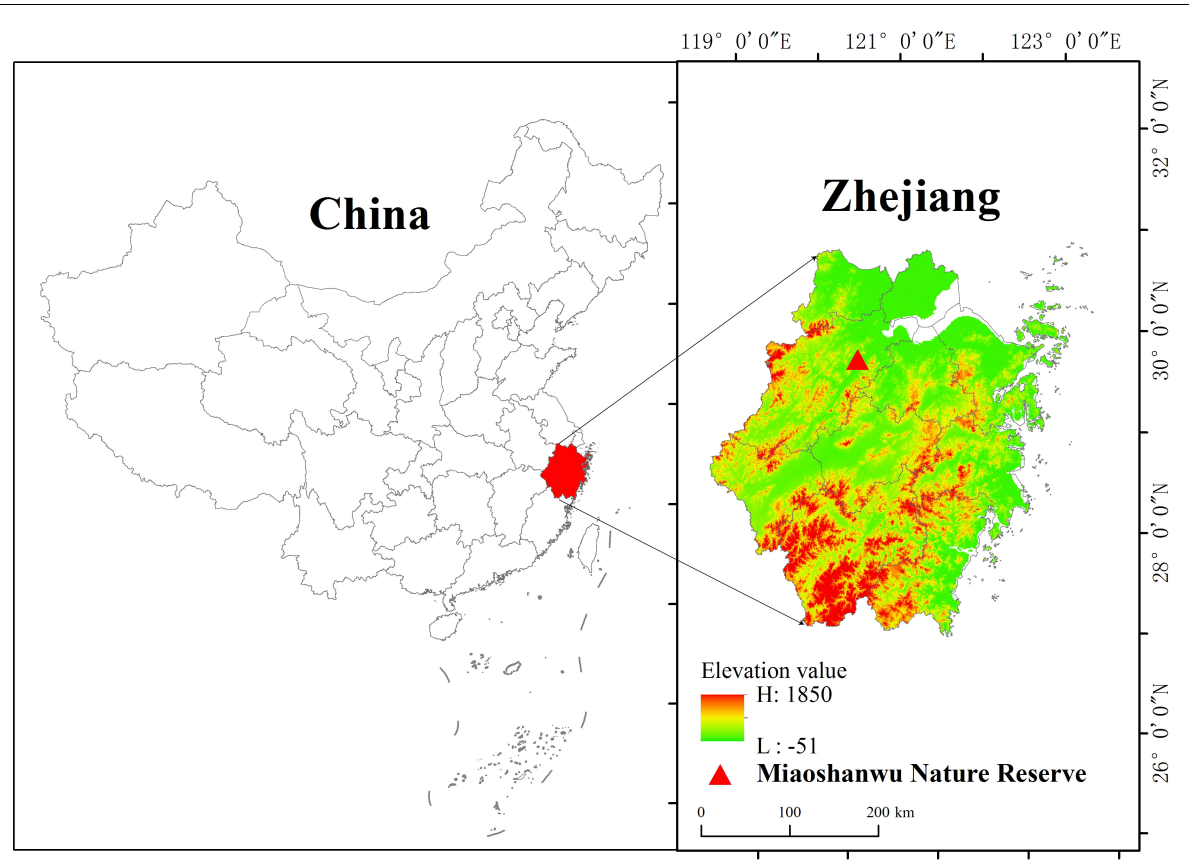

FIGURE 1 | Location of the experimental forest, Miaoshanwu Nature Reserve, Zhejiang province, China.

TABLE 1 | Physicochemical properties (mean \pm standard error; $n=3$ ) of the sites where the litter decomposition experiment was conducted.

\begin{tabular}{|c|c|c|c|c|c|}
\hline pH & Organic matter (g/kg) & Bulk density $\left(\mathrm{mg} / \mathrm{cm}^{3}\right)$ & Total N (mg/g) & Rapidly available P (mg/kg) & Rapidly available K (mg/kg) \\
\hline $5.5 \pm 0.6$ & $23.68 \pm 3.05$ & $1.36 \pm 0.08$ & $1.68 \pm 0.51$ & $2.21 \pm 0.32$ & $31.24 \pm 2.65$ \\
\hline
\end{tabular}

layer at $10-15-\mathrm{cm}$ depth was excavated in each quadrat. Then, the nylon litter bags were laid in the bottom of the soil layer, and the excavated soil and dead branches and leaves were used to cover them. Subsequently, six nylon litter bags (three for RDC2 and three for RDC5) were retrieved randomly every month for 12 months. The remaining fine-root samples in the recovered nylon litter bags were removed, dried naturally, carefully brushed to remove any attached soil particles, and dried to constant mass at $60^{\circ} \mathrm{C}$. The samples were then weighed and subjected to chemical composition analysis.

\section{Chemical Analysis}

After the fine-root were removed from the litter bags, the retrieved fine-root mass was oven-dried at $65^{\circ} \mathrm{C}$ to constant mass and was then weighed. Thereafter, the oven-dried fine-root samples were ground using a mill and were then sieved through a $0.3-\mathrm{mm}$ mesh screen for measurements of the elemental concentrations. The samples were dissolved in a concentrated acidic mixture of $\mathrm{HNO}_{3}-\mathrm{HClO}_{4}(5: 1, \mathrm{v} / \mathrm{v})$ which was then heated at $160^{\circ} \mathrm{C}$ for $5 \mathrm{~h}$. $\mathrm{C}$ and $\mathrm{N}$ of fine roots were determined using an Elementar CHNS analyzer (Vario EL III, Elementar Analyzer Systeme $\mathrm{GmbH}$, Germany); the concentrations of $\mathrm{K}, \mathrm{Ca}, \mathrm{Mg}, \mathrm{Mn}$, $\mathrm{Fe}, \mathrm{Cu}, \mathrm{Zn}$, and $\mathrm{Na}$ were determined using an inductively coupled plasma (ICP-MS, Elan DRC-e, PE, United States and ICP-OES, Optima 5300 DV, PE, United States) (Yue et al., 2016; Zhang et al., 2019).

\section{Data Analysis}

The fine-root decomposition rate constant $\mathrm{k}$ was calculated using the following exponential equation (Olson, 1963):

$$
y=M_{\mathrm{t}} / M_{0}=a e^{-\mathrm{kt}}
$$

where $M_{0}$ is the initial dry weight of fine roots $(g), M_{t}$ is the dry weight of fine roots after a period of time $(\mathrm{g})$, $\mathrm{t}$ represents the sampling time (months), and a is a fitting parameter.

The half-life and turnover periods of fine-root decomposition were estimated using the $k$ value:

$$
\begin{aligned}
& t_{0.5}=\ln 0.5 /(-k) \\
& t_{0.95}=\ln 0.05 /(-k)
\end{aligned}
$$

The remaining percentage of the mineral elements at a certain stage were calculated as:

$$
R=M_{\mathrm{t}} C_{\mathrm{t}} /\left(M_{0} C_{0}\right) \times 100 \%(t=1,2,3,4 \ldots \ldots)
$$

where $\mathrm{C}_{0}$ is the fine-root initial element concentration $(\mathrm{g} / \mathrm{kg})$, $\mathrm{C}_{t}$ is the fine-root element concentration after a period of time $(\mathrm{g} / \mathrm{kg}), \mathrm{t}$ represents the sampling time (months), and $\mathrm{k}$ is the decomposition constant.

One-way ANOVA was used to examine the differences in initial concentration of fine-root elements. Two-way ANOVA was used to examine the effects of fine-root diameter class, 
decomposition time, and their interaction on the residual rate in the process of nutrient decomposition. All statistical analyses were performed using SPSS (version 23.0; IBM SPSS Statistics for Windows, IBM Corp., Armonk, NY, United States) with a significance level of 0.05 .

\section{RESULTS}

\section{Pattern of Variation of Fine-Root Mass in Litter Bags}

The remaining rates of RDC5 and RDC2 were the same over the first 2 months. After 2 months, the remaining rate gradually diverged until after 12 months when they were $48.53 \%$ (RDC2) and 56.26\% (RDC5) (Figure 2). As shown in Table 2, the regression analysis showed that the time required for $50 \%$ decomposition of dry matter in the RDC5 and RDC2 diameter groups was 11.44 and 9.49 months, respectively. Furthermore, the time required for $95 \%$ dry matter decomposition was 49.50 months and 41.10 months, respectively. The decomposition constant rate of fine roots varied among root types (Table 2 ) with that of RDC2 being higher $(k=0.07)$ than that of $\operatorname{RDC} 5(k=0.06)$.

\section{Characteristics of Initial Content of Nutrient Elements in Fine Roots}

As shown in Table 3, in RDC5 fine roots, the initial element concentration from large to small ranked in the following order: $\mathrm{C}>\mathrm{N}>\mathrm{K}>\mathrm{P}>\mathrm{Mg}>\mathrm{Fe}>\mathrm{Mn}>\mathrm{Zn}>\mathrm{Ca}>\mathrm{Cu}$,

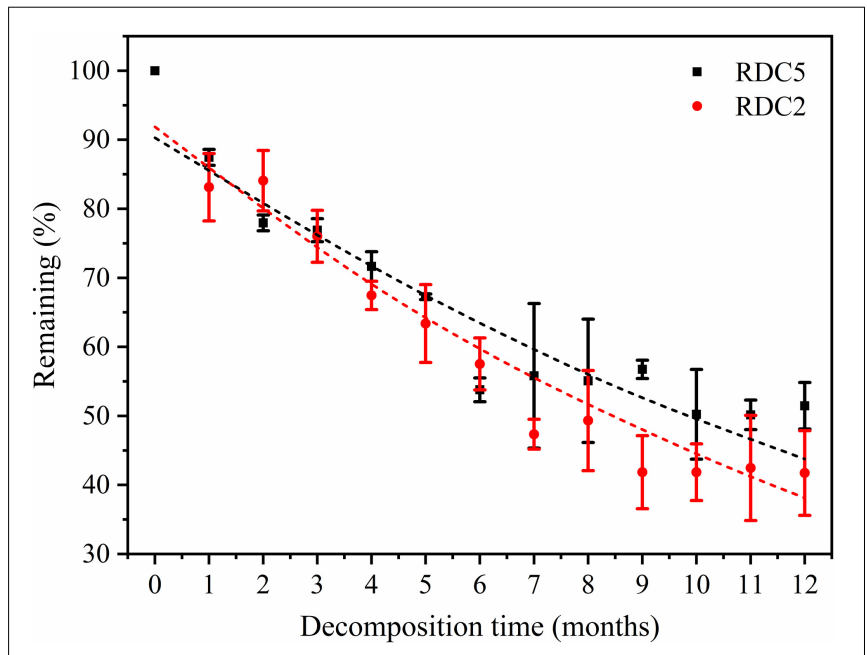

FIGURE 2 | Dry-matter mass loss during fine-root decomposition.

TABLE 2 | Decomposition parameters and time required for two fine-root diameter groups to decay ( $t_{50}$ and $t_{95}$ dry matter loss).

Diameter class Time of decomposition Time of decomposition $R^{2} k$

\begin{tabular}{|c|c|c|c|}
\hline & $50 \%$ (months) & $95 \%$ (months) & \\
\hline RDC5 & 11.44 & 49.50 & 0.850 .06 \\
\hline $\mathrm{RDC2}$ & 9.49 & 41.10 & 0.920 .07 \\
\hline
\end{tabular}

while in fine roots of the RDC2 group, the initial element concentration from large to small ranked as follows: $\mathrm{C}>\mathrm{N}>\mathrm{K}>\mathrm{Fe}>\mathrm{P}>\mathrm{Mg}>\mathrm{Mn}>\mathrm{Zn}>\mathrm{Cu}>\mathrm{Ca} . \mathrm{Cu}$, $\mathrm{Fe}, \mathrm{Zn}$, and $\mathrm{Mn}$ concentrations in RDC2 fine roots were 5. 42-, 2. 83-, 2. 49-, and 2.12-fold higher than those in the RDC5 group, respectively, and $\mathrm{N}, \mathrm{K}$, and $\mathrm{Mg}$ concentrations were also higher. In addition, the $\mathrm{C} / \mathrm{N}$ ratio in $\mathrm{RDC} 2$ fine roots was less than that of RDC5 fine roots.

\section{Dynamic Patterns of Different Root Elements in Litter Bags}

Figure 3 shows that in the process of fine-root decomposition, the loss of $\mathrm{C}$ was significantly greater in the early stages (1-6 months) than in the late stages (6-12 months). The remaining $\mathrm{C}$ of the two diameter classes under study was $86.94 \%$ (RDC5) and $83.6 \%$ (RDC2) after 1 month, which then gradually decreased (Figure 3). In the seventh month, the remaining $\mathrm{C}$ in RDC5 and RDC2 was 50.79 and $44.88 \%$, respectively, after which the loss rate of the remaining $\mathrm{C}$ decreased gradually In addition, the change rate of the remaining of $\mathrm{C}$ observed for the RDC2 diameter group was slightly lower than that for the RDC5 diameter group.

Figure 3 shows that 1 month after decomposition, the remaining $\mathrm{N}$ in the fine roots was $68.33 \%$ (RDC5) and $53.8 \%$ (RDC2). At 12 months, the remaining $\mathrm{N}$ was $48.71 \%$ (RDC5) and $38.08 \%$ (RDC2). Over 12 -months decomposition process the remaining $\mathrm{N}$ was always higher in RDC5 than in RDC2 fine roots. In addition, there was a small increase in $\mathrm{N}$ remaining in RDC5 at 7 and 10 months.

Figure 3 shows that the remaining $\mathrm{P}$ decreased sharply over the first 2 months, with only approximately $45 \%$ left in RDC2 and RDC5 at that time, after which the remaining $\mathrm{P}$ fluctuated. After 12 months, the remaining P was 32.39\% (RDC5) and $35.88 \%$ (RDC2).

Similarly, the remaining percentage of $\mathrm{K}$ in the two groups of fine-root changed sharply in the early stages, whereas it tended to be stable in the later stages. During fine-root decomposition, the remaining $\mathrm{Mg}$ decreased gradually to $52.67 \%$ (RDC5) and $65.26 \%$ (RDC2) after 12 months (Figure 3).

Figure 3 shows that in the process of fine-root decomposition of the two groups under study here, Ca increased at first and then decreased gradually. After 12 months, the remaining $\mathrm{Ca}$ in the two groups of fine roots was approximately $40 \%$ and did not differ significantly between groups. The remaining Fe in RDC5 was more than $100 \%$ during the experimental period (12 months), indicating enrichment. The remaining Fe in RDC2 fluctuated around $100 \%$ during the 12 -month experimental period. After 12 months, the remaining Fe of RDC5 and RDC2 was 175.86 and $107.16 \%$, respectively.

Figure 3 shows that the variation in the remaining $\mathrm{Mn}$ in the two groups of fine roots differed considerably, with that in RDC5 fluctuating sharply, until 12 months later, when the remaining Mn was $83.13 \%$. The remaining Mn in RDC2 changed more gently and decreased gradually while fluctuating, until after 12 months, when the remaining $\mathrm{Mn}$ was $61.09 \%$. In turn, $\mathrm{Zn}$ showed a release-enrichment-release dynamic in the two groups. 
TABLE 3 | Initial concentration of nutrients in litter from bamboo roots of different diameters.

\begin{tabular}{|c|c|c|c|c|c|c|}
\hline Root size & C \% & $\mathbf{N ~ g / k g}$ & $\mathrm{P} \mathrm{g} / \mathrm{kg}$ & $\mathrm{K} \mathrm{g} / \mathbf{k g}$ & $\mathrm{Ca} \mathrm{g} / \mathbf{k g}$ & $\mathrm{Mg} \mathrm{g} / \mathbf{k g}$ \\
\hline RDC5 & $46.89 \pm 3.12 a$ & $6.05 \pm 1.09 a$ & $2.03 \pm 0.32 a$ & $5.16 \pm 0.52 a$ & $0.19 \pm 0.08 a$ & $1.38 \pm 0.77 a$ \\
\hline RDC2 & $44.41 \pm 1.54 a$ & $10.45 \pm 0.87 b$ & $1.99 \pm 0.51 a$ & $8.86 \pm 1.43 b$ & $0.12 \pm 0.08 a$ & $1.67 \pm 0.21 a$ \\
\hline Root size & $\mathrm{Fe} \mathrm{g} / \mathrm{kg}$ & $\mathrm{Mn} \mathrm{g} / \mathrm{kg}$ & Zn mg/kg & Cu mg/kg & $\mathrm{C} / \mathrm{N}$ ratio & \\
\hline RDC5 & $1.05 \pm 0.31 a$ & $0.10 \pm 0.01 a$ & $52.95 \pm 8.76 a$ & $8.33 \pm 3.01 a$ & $77.54 \pm 9.98 a$ & \\
\hline RDC2 & $2.97 \pm 0.78 b$ & $0.22 \pm 0.06 b$ & $131.92 \pm 10.90 b$ & $45.15 \pm 7.90 b$ & $42.49 \pm 3.21 b$ & \\
\hline
\end{tabular}

Values followed by different letters on the same column indicate significant differences at $P<0.05$.
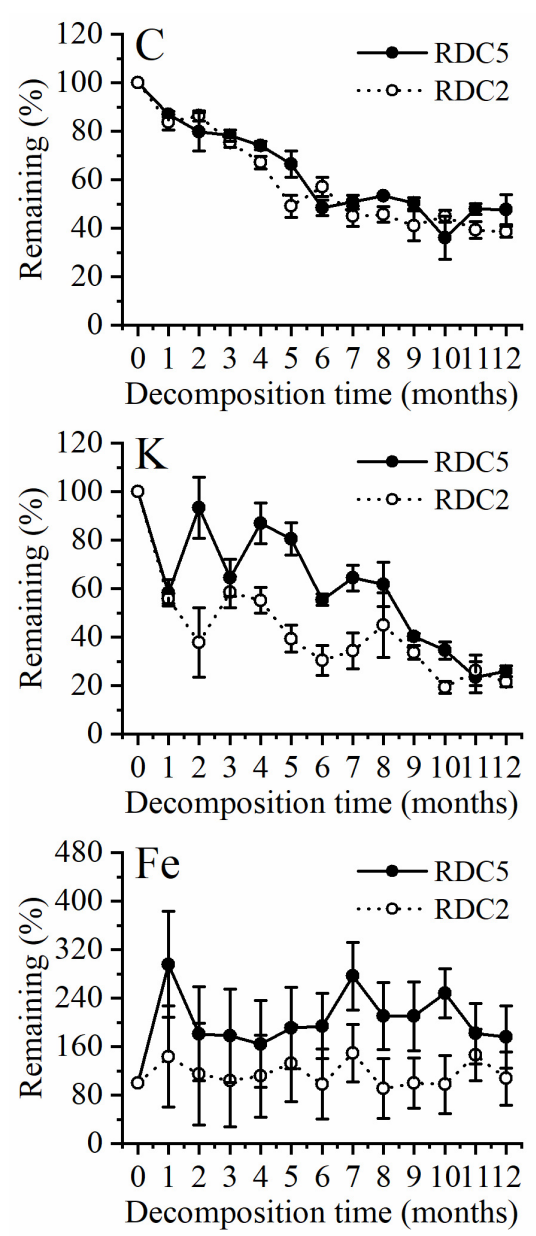

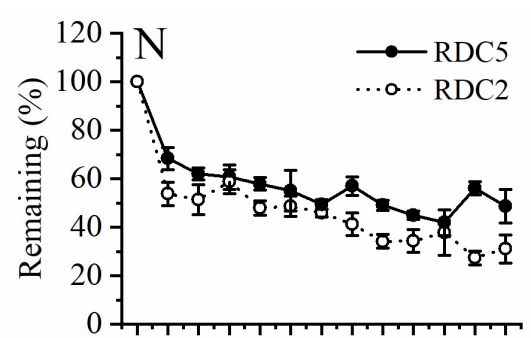

$0 \begin{array}{llllllllll}0 & 2 & 3 & 4 & 5 & 6 & 8 & 8 & 101112\end{array}$

Decomposition time (months)
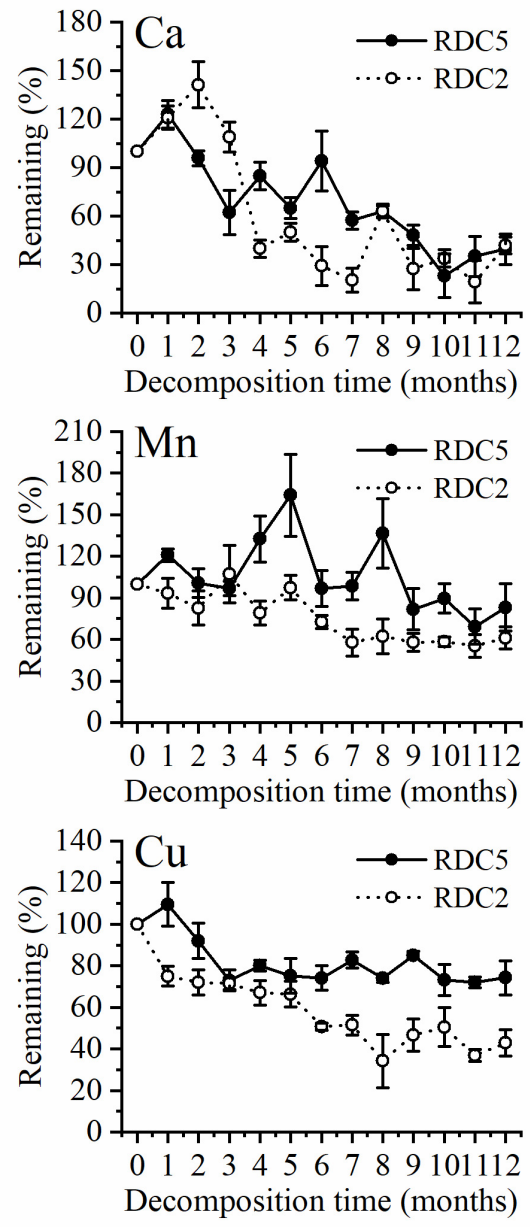
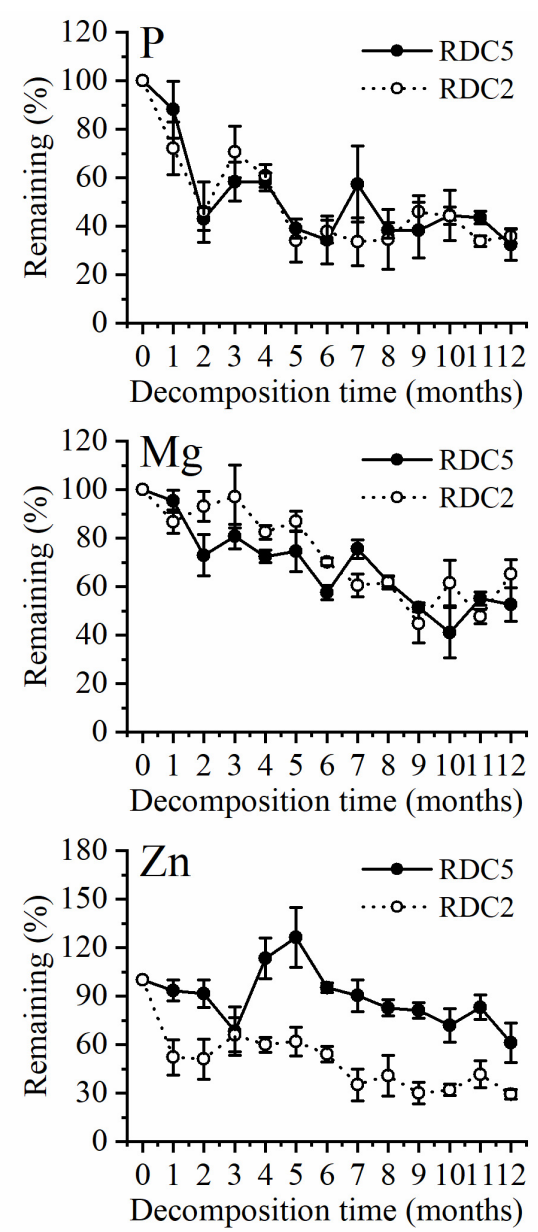

FIGURE 3 | Change trend in element remaining percentage during fine-root decomposition. 


\section{Effect of Decomposition Time and Root Diameter on Remaining Percentage}

The two-way ANOVA results showed that root diameter and decomposition time had significant effects on $\mathrm{C}, \mathrm{N}, \mathrm{K}, \mathrm{Ca}, \mathrm{Mg}$, $\mathrm{Mn}, \mathrm{Zn}$, and $\mathrm{Cu}$; furthermore, significant interactive effects for most elements $(P<0.05)$ were detected. Phosphorus and Fe in root material were only affected by time and root diameter, respectively (Table 4).

\section{DISCUSSION}

\section{Mass Loss During Fine-Root Decomposition}

The results showed that the decomposition of fine roots of moso bamboo was not constant. Fine-root decomposition is the process of material exchange with the surrounding environment. Fine-root material re-enters the soil under the action of microorganisms (Burton et al., 2000). Some studies suggest that plant decomposition is controlled by the vegetative strategies of fungal groups, which in turn may be controlled by r-type

TABLE 4 | Two-way ANOVA for decomposition time and root diameter effects on element remaining percentage.

\begin{tabular}{|c|c|c|c|c|}
\hline Item & Factor & df & $\boldsymbol{F}$ & $P$ \\
\hline \multirow[t]{3}{*}{ C } & Root diameter & 1 & 11.344 & $<0.001$ \\
\hline & Decomposition time & 11 & 65.656 & $<0.001$ \\
\hline & Root diameter $\times$ Decomposition time & 11 & 3.987 & 0.001 \\
\hline \multirow[t]{3}{*}{ N } & Root diameter & 1 & 73.317 & $<0.001$ \\
\hline & Decomposition time & 11 & 11.724 & $<0.001$ \\
\hline & Root diameter $\times$ Decomposition time & 11 & 2.518 & 0.014 \\
\hline \multirow[t]{3}{*}{$P$} & Root diameter & 1 & 0.773 & 0.384 \\
\hline & Decomposition time & 11 & 10.944 & $<0.001$ \\
\hline & Root diameter $\times$ Decomposition time & 11 & 1.433 & 0.19 \\
\hline \multirow[t]{3}{*}{ K } & Root diameter & 1 & 91.043 & $<0.001$ \\
\hline & Decomposition time & 11 & 22.112 & $<0.001$ \\
\hline & Root diameter $\times$ Decomposition time & 11 & 6.403 & $<0.001$ \\
\hline \multirow[t]{3}{*}{$\mathrm{Ca}$} & Root diameter & 1 & 8.609 & 0.005 \\
\hline & Decomposition time & 11 & 43.127 & $<0.001$ \\
\hline & Root diameter $\times$ Decomposition time & 11 & 11.591 & $<0.001$ \\
\hline \multirow[t]{3}{*}{ Mg } & Root diameter & 1 & 10.101 & 0.003 \\
\hline & Decomposition time & 11 & 25.163 & $<0.001$ \\
\hline & Root diameter $\times$ Decomposition time & 11 & 4.247 & $<0.001$ \\
\hline \multirow[t]{3}{*}{$\mathrm{Fe}$} & Root diameter & 1 & 30.4 & $<0.001$ \\
\hline & Decomposition time & 11 & 0.866 & 0.578 \\
\hline & Root diameter $\times$ Decomposition time & 11 & 0.449 & 0.925 \\
\hline \multirow[t]{3}{*}{ Mn } & Root diameter & 1 & 69.438 & $<0.001$ \\
\hline & Decomposition time & 11 & 8.885 & $<0.001$ \\
\hline & Root diameter $\times$ Decomposition time & 11 & 3.112 & 0.003 \\
\hline \multirow[t]{3}{*}{$\mathrm{Zn}$} & Root diameter & 1 & 227.802 & $<0.001$ \\
\hline & Decomposition time & 11 & 8.182 & $<0.001$ \\
\hline & Root diameter $\times$ Decomposition time & 11 & 2.512 & 0.014 \\
\hline \multirow[t]{3}{*}{$\mathrm{Cu}$} & Root diameter & 1 & 175.904 & $<0.001$ \\
\hline & Decomposition time & 11 & 11.85 & $<0.001$ \\
\hline & Root diameter $\times$ Decomposition time & 11 & 3.541 & 0.001 \\
\hline
\end{tabular}

strategists (such as Mucorales) sensitive to fresh organic matter and nutrients in the early stages of decomposition. Then, when the soluble organic matter is exhausted, k-type strategists (such as Eurotiales and Agaricales) decompose refractory organic matter, such as cellulose and lignin, thus controlling the process at this stage (Venkatesagowda, 2019). Therefore, the differences in nutrient strategies and microbial ecological niches during decomposition may be the ultimate cause for the different decomposition rates observed. A previous study showed that fine-root decomposition way inversely correlated to the lignin: $\mathrm{N}$ ratio, with fine and small roots showing higher lignin: $\mathrm{N}$ ratios (Fujimaki et al., 2008); this may explain why RDC2 had a higher constant decomposition rate. In addition, there are significant differences in $\mathrm{N}$ concentration in moso Bamboo roots of different growth stages (Li et al., 1998), which will affect the decomposition of roots. Therefore, in future work, we will study the effects of different growth stages on root decomposition in moso bamboo.

The relationship between decomposition of fine roots and climatic conditions was found to be weak, even though the decomposition of bamboo is related to seasonal variation in precipitation (Fujimaki et al., 2008). Differences in moisture conditions also do not explain faster litter decomposition in a temperate forest, thus differences were speculated to be speciesspecific and dependent on the initial root chemistry rather than local climate (Fujimaki et al., 2008).

\section{Release of Nutrient Elements in the Litter Bags}

This study showed that the decomposition of RDC2 fine roots was faster than that of the RDC5 group. In general, the thinner the roots, the greater the ratio of surface area to volume, and the larger the surface contact with the surroundings, which is conducive to the invasion and decomposition of microorganisms. Many studies have found that $\mathrm{N}$ content decreases and $\mathrm{C} / \mathrm{N}$ increases with root diameter and substrates with higher $\mathrm{C} / \mathrm{N}$ denote higher concentrations of structural substances; concomitantly, $\mathrm{N}$ is less available and therefore more difficult to decompose (Pregitzer et al., 2002; Yang et al., 2004). Silver and Miya (2001) collected global root data and found that broad-leaved species tend to decompose faster than coniferous species because broad-leaved species have higher $\mathrm{N}$ concentrations and lower $\mathrm{C} / \mathrm{N}$ ratios.

It was found in this study that the remaining of $\mathrm{C}$ and $\mathrm{N}$ both showed a slight upward fluctuation in the process of gradual decline. $\mathrm{C}$ is the main constituent of organic matter, and its release usually shows a linear change with the decrease in litter mass. Furthermore, $\mathrm{C}$ showed a direct release mode in a previous study (Moore et al., 2006). Another, study found that $\mathrm{N}$ is enriched in the process of root decomposition (Chen et al., 2001). Biological degradation of litter is mainly performed by microorganisms such as fungi and bacteria, which have lower $\mathrm{C} / \mathrm{N}$ values than most types of litter. Therefore, $\mathrm{C}$ and $\mathrm{N}$ are only net released in the form of minerals when the $\mathrm{C} / \mathrm{N}$ values of plant residues reach critical levels (Manzoni et al., 2008). Thus, in this study, the remaining $\mathrm{C}$ and $\mathrm{N}$ both showed slight upward 
fluctuation in the process of gradual decline may be trying to sustain the $\mathrm{C} / \mathrm{N}$ values of plant residues.

As for P, our results showed a release-enrichment-release pattern during fine-root decomposition, as well as a $\mathrm{P}$ release pattern during fine-root decomposition. However, evidence has been reported suggesting that $\mathrm{P}$ is released during grass root decomposition in a steppe, whereas it tended to be immobilized in forests (Gargaglione et al., 2018). An explanation of this discrepancy may involve the N/P ratio. A previous study reported that litter with $\mathrm{N} / \mathrm{P}>22$ tends to be immobilized during decomposition but litter with a lower N/P ratio may tend to show P immobilization or mineralization (Güsewell and Freeman, 2005). Meanwhile, the concentration of $K$ was fluctuating, and several studies that have shown that $\mathrm{K}$ is involved in a typical direct release mode (Edmonds and Tuttle, 2010; Gargaglione et al., 2018). A possible reason is that $\mathrm{K}$ is mainly present in the solution of plant cells in the form of ions that are released directly mainly through leaching rather than in the form of structural substances (Osono and Takeda, 2004). The experimental area was located in the subtropical zone with frequent precipitation, and the change in soil water content may be the reason for this phenomenon.

The remaining $\mathrm{Ca}$ and $\mathrm{Mg}$ in the fine roots of moso bamboo gradually decreased during the alternating process of enrichment and release. $\mathrm{Ca}$ and $\mathrm{Mg}$ mainly exist in plants in the form of chelates, and at the early stages of decomposition, the chelate macromolecules gradually disintegrate and $\mathrm{Ca}$ and $\mathrm{Mg}$ are freed. With the increase in temperature and rainfall, $\mathrm{Ca}$ and $\mathrm{Mg}$ were released from the litter (Whitford et al., 1995). Therefore, temperature and precipitation will have a strong impact on the release of $\mathrm{Ca}$ and $\mathrm{Mg}$, which may be the reason why the remaining $\mathrm{Ca}$ and $\mathrm{Mg}$ gradually decreased in the alternating periods of enrichment and release.

This study showed that the remaining metal elements $\mathrm{Mn}$, $\mathrm{Mg}$, and Fe exceeded 50\% after 12 months, and these elements are more difficult to release than non-metallic elements. The same phenomenon was found in some leaf decomposition experiments, suggesting that as organic matter components, Mn, $\mathrm{Mg}$, and Fe are difficult for microorganisms to decompose and use which may be the cause of their enrichment in the soil (Berg et al., 2010). To date, the mechanism of the increase in the remainder of some elements during the decomposition of plant residues remains unclear. Other previous studies focused on heavy metal elements in the process of decomposition of plant residues and observed an absolute increase (Edmonds and Tuttle, 2010; Nikolaidou et al., 2010). Some of these reports suggested that this kind of element enrichment during the decomposition process may be controlled by biological and chemical factors, namely, heavy metal elements may become strongly fixed by forming highly stable chelates as part of the chemical formation of humic acids (Rustad and Cronan, 1988).

\section{Reflections and Prospects of Fine-Root Decomposition}

Fine-root decomposition is a complex physical, chemical, and biological process (Figure 4). The factors affecting the decomposition process, the resulting plant elements, and nutrient release include the environment, litter quality and quantity, the microbial community, and the complex interrelationships among these factors (Smith et al., 2014). The extent of their influence is usually ordered as follows: environment $>$ litter quality $>$ microbial community (Aerts, 2006). Previous studies assumed that the environment was the key factor in determining decomposition, while litter quality only played a role when the environmental influence was not evident. In this scheme, the microbial community was thought not to affect the decomposition process directly but to be determined by the environment and litter quality, depending on which, it then exerted an effect on decomposition. However, an increasing

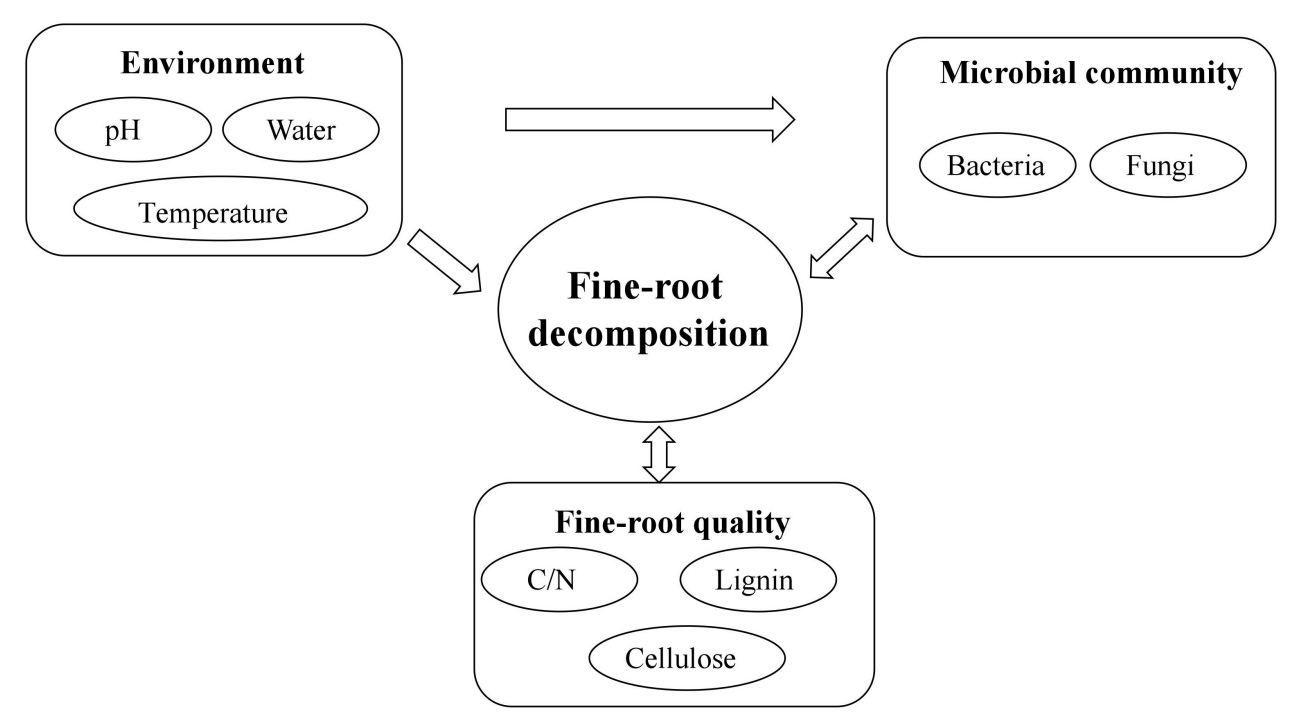

FIGURE 4 | Factors controlling fine-root decomposition and their interactions. 
number of studies have found that on a very small scale, the microbial community is the key factor directly affecting decomposition (Bradford et al., 2016). Currently, the importance and role of each factor in different ecosystems and at different stages of decomposition are assumed to vary, although the mechanisms are not clear (Gracia-Palacios et al., 2013). Therefore, it is important to pay attention to the study of fine-root decomposition processes at a small regional scale, and to determine the causes and threshold levels of changes in dominant factors of decomposition in future fine root research.

\section{CONCLUSION}

This is the first extensive report on the changes in the concentrations of 10 mineral elements during fine-root decomposition in a moso bamboo forest. Our experiments showed that initial element concentration and decomposition of fine roots with different diameters are different with finer roots (diameter $<2 \mathrm{~mm}$ ) decomposing faster. In general, $\mathrm{C}, \mathrm{N}, \mathrm{P}, \mathrm{K}, \mathrm{Ca}$, and $\mathrm{Mg}$ were released, whereas $\mathrm{Fe}, \mathrm{Mn}$, $\mathrm{Zn}$, and $\mathrm{Cu}$ were either enriched or unchanged to any significant extent. In addition, the release and enrichment of elements during the decomposition process were not linear but rather fluctuated. Our findings thus lay a solid theoretical foundation for further research on the mechanism of plant-soil

\section{REFERENCES}

Aerts, R. (2006). The freezer defrosting: global warming and litter decomposition rates in cold biomes. J. Ecol. 94, 713-724. doi: 10.1111/j.1365-2745.2006.01142.x

Berg, B., Davey, M. P., Marco, A. D., Emmett, B., Faituri, M., Hobbie, S. E., et al. (2010). Factors influencing limit values for pine needle litter decomposition: a synthesis for boreal and temperate pine forest systems. Biogeochemistry 100, 57-73. doi: 10.1007/s10533-009-9404-y

Blair, J. M. (1988). Nitrogen, sulfur and phosphorus dynamics in decomposing deciduous leaf litter in the southern Appalachians. Soil Biol. Biochem. 20, 693-701. doi: 10.1016/0038-0717(88)90154-X

Bradford, M. A., Berg, B., Maynard, D. S., Wieder, W. R., and Wood, S. A. (2016). Understanding the dominant controls on litter decomposition. J. Ecol. 104, 229-238. doi: 10.1111/1365-2745.12507

Buckingham, K., Jepson, P., Wu, L., Rao, I. V., Jiang, S., Liese, W., et al. (2011). The potential of bamboo is constrained by outmoded policy frames. Ambio 40, 544-548. doi: 10.1007/s13280-011-0138-4

Burton, A. J., Pregitzer, K. S., and Hendrick, R. L. (2000). Relationships between fine root dynamics and nitrogen availability in Michigan northern hardwood forests. Oecologia 125, 389-399. doi: 10.1007/s004420000455

Chen, H., Harmon, M. E., and Griffiths, R. P. (2001). Decomposition and nitrogen release from decomposing woody roots in coniferous forests of the Pacific Northwest: a chronosequence approach. Can. J. For. Res. 31, 246-260. doi: 10.1139/cjfr-31-2-246

Dunmei, L., Mei, P., Nicolas, F., Hongjuan, W., Shenhua, Q., Liang, Z., et al. (2018). Fungi participate in driving home-field advantage of litter decomposition in a subtropical forest. Plant Soil 434, 467-480. doi: 10.1007/s11104-018-3865-5

Edmonds, R. L., and Tuttle, K. M. (2010). Red alder leaf decomposition and nutrient release in alder and conifer riparian patches in western Washington, USA. For. Ecol. Manage. 259, 2375-2381. doi: 10.1016/j.foreco.2010.03.011

Fujimaki, R., Takeda, H., and Wiwatiwitaya, D. (2008). Fine root decomposition in tropical dry evergreen and dry deciduous forests in Thailand. J. For. Res. 13, 338-346. doi: 10.1007/s10310-008-0087-3 nutrient cycling and the factors governing the process of fine-root decomposition.

\section{DATA AVAILABILITY STATEMENT}

The raw data supporting the conclusions of this article will be made available by the authors, without undue reservation.

\section{AUTHOR CONTRIBUTIONS}

BZ contributed to the conception of the study. YX contributed significantly to analysis and manuscript preparation, performed the data analyses, and wrote the manuscript. XG, RH, and BZ helped to perform the analysis with constructive discussions. All authors contributed to the article and approved the submitted version.

\section{FUNDING}

This work was supported by the National Key R\&D Program of China (No. 2021YFD220040205), National Natural Science Foundation of China (Nos. 31670607 and 32071756), and Fundamental Research Funds for the Central Non-profit Research Institution of CAF (Nos. CAFYBB2019ZD001, CAFYBB2020ZE001, and CAFYBB2017ZX002-2).

Gargaglione, V., Bahamonde, H. A., and Peri, P. L. (2018). Decomposition and nutrient release of grass and tree fine roots along an environmental gradient in Southern Patagonia. Aust. Ecol. 44, 276-289. doi: 10.1111/aec.12672

Gracia-Palacios, P., Maestre, F. T., Kattge, J., and Wall, D. H. (2013). Climate and litter quality differently modulate the effects of soil fauna on litter decomposition across biomes. Ecol. Lett. 16, 1045-1053. doi: 10.1111/ele.12137

Güsewell, S., and Freeman, C. (2005). Nutrient limitation and enzyme activities during litter decomposition of nine wetland species in relation to litter $\mathrm{N}$ : $\mathrm{P}$ ratios. Funct. Ecol. 19, 582-593. doi: 10.2307/3599219

He, L., Jia, Z., Li, Q., Feng, L., and Yang, K. (2019). Fine-root decomposition characteristics of four typical shrubs in sandy areas of an arid and semiarid alpine region in western China. Ecol. Evol. 9, 5407-5419. doi: 10.1002/ece3.5133

Hendrick, R. L., and Pregitzer, K. S. (1992). The demography of fine roots in a northern hardwood forest. Ecology 73, 1094-1104. doi: 10.2307/1940183

Li, R., Werger, M. J. A., During, H. J., and Zhong, Z. C. (1998). Carbon and nutrient dynamics in relation to growth rhythm in the giant bamboo Phyllostachys pubescens. Plant Soil 201, 113-123. doi: 10.1023/A:1004322812651

Manzoni, S., Jackson, R. B., Trofymow, J. A., and Porporato, A. (2008). The global stoichiometry of litter nitrogen mineralization. Science 32, 684-686. doi: 10. 1126/science. 1159792

Moore, T. R., Trofymow, J. A., Prescott, C. E., Fyles, J., and Group, B. D. T. W. (2006). Patterns of carbon, nitrogen and phosphorus dynamics in decomposing foliar litter in Canadian forests. Ecosystems 9, 46-62. doi: 10.1007/s10021-0040026-x

Nikolaidou, A. E., Pavlatou-Ve, A. K., Kostopoulou, S. K., Mamolos, A. P., and Kalburtji, K. L. (2010). Litter quality and decomposition of Vitis vinifera L. residues under organic and conventional farming systems. Eur. J. Soil Biol. 46, 208-217. doi: 10.1016/j.ejsobi.2010.03.001

Olson, J. S. (1963). Energy storage and the balance of producers and decomposers in ecological systems. Ecology 44, 322-331. doi: 10.2307/1932179

Osono, T., and Takeda, H. (2004). Potassium, calcium, and magnesium dynamics during litter decomposition in a cool temperate forest. J. For. Res. 9, 23-31. doi: $10.1007 / \mathrm{s} 10310-003-0047-\mathrm{x}$ 
Pregitzer, K. S., Deforest, J. D., Burton, A. J., Allen, M. F., Ruess, R. W., and Hendrick, R. L. (2002). Fine root architecture of nine North American trees. Ecol. Manage. 72, 293-309. doi: 10.2307/3100029

Rustad, L. E., and Cronan, C. S. (1988). Element loss and retention during litter decay in a red spruce stand in Maine. Can. J. For. Res. 18, 947-953. doi: 10.1139/x88-144

Silver, W. L., and Miya, R. K. (2001). Global patterns in root decomposition: comparisons of climate and litter quality effects. Oecologia 129, 407-419. doi: 10.1007/s004420100740

Smith, S. W., Woodin, S. J., Pakeman, R. J., Johnson, D., and van der Wal, R. (2014). Root traits predict decomposition across a landscape-scale grazing experiment. New Phytol. 203, 851-862. doi: 10.1111/nph.12845

Usman, S., Singh, S. P., Rawat, Y. S., and Bargali, S. S. (2000). Fine root decomposition and nitrogen mineralisation patterns in Quercus leucotrichophora and Pinus roxburghii forests in central Himalaya. For. Ecol. Manage. 131, 191-199. doi: 10.1016/S0378-1127(99)00213-3

Venkatesagowda, B. (2019). Enzymatic demethylation of lignin for potential biobased polymer applications. Fungal Biol. Rev. 33, 190-224. doi: 10.1016/j. fbr.2019.06.002

Vogt, K. A., Grier, C. C., and Vogt, D. J. (1986). Production, turnover, and nutrient dynamics of above- and belowground detritus of world forests. Adv. Ecol. Res. 15, 303-377. doi: 10.1016/S0065-2504(08)60122-1

Wang, W., Zhang, X., Tao, N., Ao, D., Zeng, W., Qian, Y., et al. (2014). Effects of litter types, microsite and root diameters on litter decomposition in Pinus sylvestris plantations of northern China. Plant Soil 374, 677-688. doi: 10.1007/ s11104-013-1902-y

Whitford, W. G., Martinez-Turanzas, G., and Martinez-Meza, E. (1995). Persistence of desertified ecosystems: explanations and implications. Environ. Monit. Assess. 37, 319-332. doi: 10.1007/BF00546898

Xu, W., Liu, J., Liu, X., Li, K., Zhang, D., and Yan, J. (2013). Fine root production, turnover, and decomposition in a fast-growth Eucalyptus urophylla plantation in southern China. J. Soils Sediments 13, 1150-1160. doi: 10.1007/s11368-0130718-y

Yang, C., Zhang, X., Ni, H., Gai, X., and Zhong, Z. (2021). Soil carbon and associated bacterial community shifts driven by fine root traits along a chronosequence of Moso bamboo (Phyllostachys edulis) plantations in subtropical China. Sci. Total Environ. 752:142333. doi: 10.1016/j.scitotenv.2020. 142333

Yang, Y. S., Chen, G. S., Guo, J. F., and Lin, P. (2004). Decomposition dynamic of fine roots in a mixed forest of Cunninghamia lanceolata and Tsoongiodendron odorum in mid-subtropics. Ann. For. Sci. 61, 65-72. doi: 10.1051/forest:200 3085

Yuan, Z. Y., and Chen, H. Y. H. (2010). Fine root biomass, production, turn-over rates, and nutrient contents in boreal forest ecosystems in relation to species, climate, fertility, and stand age: literature review and meta-analyses. Crit. Rev. Plant Sci. 29, 204-221. doi: 10.1080/07352689.2010.483579

Yue, K., Yang, W. Q., Peng, Y., Zhang, C., Huang, C. P., Xu, Z. F., et al. (2016). Dynamics of multiple metallic elements during foliar litter decomposition in an alpine forest river. Ann. For. Sci. 73, 547-557. doi: 10.1007/s13595-016-0549-2

Zhang, L., Liu, J., and Zhang, Y. (2019). Distribution characteristics of rare earth elements in plants and soils from the Bayan Obo mining area (in Chinese). Rock Min. Anal. 38, 556-564. doi: 10.15898/j.cnki.11-2131/td.20180920 0107

Conflict of Interest: The authors declare that the research was conducted in the absence of any commercial or financial relationships that could be construed as a potential conflict of interest.

Publisher's Note: All claims expressed in this article are solely those of the authors and do not necessarily represent those of their affiliated organizations, or those of the publisher, the editors and the reviewers. Any product that may be evaluated in this article, or claim that may be made by its manufacturer, is not guaranteed or endorsed by the publisher.

Copyright (c) $2022 \mathrm{Xu}$, Huang, Zhou and Ge. This is an open-access article distributed under the terms of the Creative Commons Attribution License (CC BY). The use, distribution or reproduction in other forums is permitted, provided the original author(s) and the copyright owner(s) are credited and that the original publication in this journal is cited, in accordance with accepted academic practice. No use, distribution or reproduction is permitted which does not comply with these terms. 